\title{
Teachers: key factors for preparing students to contribute in a democratic society
}

\author{
Prof. Assoc. Dr. Bahtije Gerbeshi Zylfiu \\ University of Prishtina, Faculty of Education \\ bahtie_gerbeshi@hotmail.com
}

DOI:10.5901/mjss.2014.v5n19p234

\begin{abstract}
Kosovar society is facing social reforms. Deep reforms are being conducted in the field of education. Education in Kosovo aims to prepare its citizens to live in a democratic society. In this context, teachers have a major role. Through civic education, they have the opportunity to help their students develop the knowledge, skills, attitudes and values required in a democratic society. The purpose of this study is to present the teacher's role for preparing students to contribute in democratic society. Also, in this paper we will present the opinions of the students about the role of their teachers for citizenship education. The research was conducted in 142 primary schools in rural and urban areas. The research included Kosovar students of different nationalities, social backgrounds, religions, genders, etc. A standardized questionnaire has been used for the research and, as the research involves a rather large number of respondents (1700), we consider that the findings of this survey are representative of all primary schools in Kosovo. In each of the schools where the research was conducted, an eighth class was selected, and within that same class, 10 students were selected to participate in the research. The selection of classes was done based on the following criteria: in the first school, the first class was selected, in the second school, middle classes were selected, and consequently, in the third school, the last classes were selected. This method was used in all the schools included in the research. Students were selected randomly applying thus the principle of random sampling. Analysis of the data shows the teachers' role in preparing their students to overcome the challenges they face, and on the other hand, their role in preparing their students in democratic spirit. In the end we can say that the findings from this research will help teachers and other relevant stakeholders to develop democracy and promote its values.
\end{abstract}

Keywords: Teachers; Education; Democracy; Students; Kosovo.

\section{Introduction}

The new millennium is characterized by the rapid developments in science, techniques, technology and profound social changes that are a result of these developments. Moving forward along with these changes, the education continues to be the safest option. A different and qualitative education would help different population to become part of a large European family.

Since Kosovo seeks European and Euro-Atlantic integration, the only safe way for Kosovars to achieve their goals is the education of young people in a democratic spirit. Considering that the most significant institutions for education of the young people in Kosovo are schools, therefore, their role and the teachers' role is undeniable and irreplaceable. Teachers should care about education, awareness, information, training and equipping students with knowledge, skills, attitudes and behaviour which enable and empower them to exercise and protect their rights and responsibilities in society. "If you ask teachers what their job is, they will overwhelmingly emphasize the importance of their work in the classroom: teaching students fundamental knowledge and skills to develop proficiency in a subject area and fostering attitudes necessary to equip them to be productive workers, lifelong learners, and responsible citizens (Zmuda, 2004, p. 8)". In addition, teachers prepare their students to appreciate the diversity and equality among people, to play an active role in democratic life, as well as to protect and develop the democracy in our country. Also, teachers with their work and commitment encourage social cohesion, and evaluate the changes, especially among religious and ethnic groups by resolving disagreements peacefully, respecting the rights of others, fighting all forms of discrimination and violence. However, one should not forget that, to achieve these objectives, professional preparation of teachers requires additional knowledge.

The main purpose of this paper is to present the role of the teachers in preparing students to contribute to a democratic society. Also, this paper will talk about other issues dealing with teachers as agents of change, the steps being taken on permanent development of the profession of teachers, etc..., and will present the results of the field research that relate to students' opinions concerning this issue. Their opinions are substantial knowing that students are teachers' best assessors. 
The outcomes of this research show that teachers are key factors that enable and facilitate the preparation of the Kosovar youth to be responsible and active citizens in order to contribute towards development of a society with democratic values.

In our opinion, considering the overall situation in Kosovo, according to democratic principles, the focus on scientific research related to civic education is of particular importance. Through these surveys we can provide data, analysis of which create a clear picture regarding the overall changes on the field of education in general, and in the development of the democratic processes on particular. Even under the European Council Charter on education for democratic citizenship and human rights, member states are encouraged to start and foster researches on education for democratic citizenship and human rights. These studies will help to recognize the current situation in this field and to provide education stakeholders, policy makers, education institutions, school administrators, teachers, students, non-governmental organizations and youth organizations with comparative information that will help them to measure and enhance the effectiveness and efficiency of their work and practices.

In this context, we can say that this paper of ours is a modest contribution that addresses the role of teachers in preparing students for the development of a democratic society that will encourage and motivate teachers to prepare new generations of trained life and to contribute to the development of democratic processes in society. On the other hand, this paper will be one more reference in the wake of studies conducted in the field of education.

The results of this study and other researches that were conducted regarding the role of teachers for development of a democratic society of Kosovo students are very important to the overall social, political and cultural time and circumstances that we are living today.

The questions raised here are the following: Do students have the opportunity to express their disagreement with the teachers? Are they encouraged by teachers to take their own decisions? Do students have the opportunity to express their opinions freely? Are political events of Kosovo and international context discussed in class, etc?

In the end we must say that, while schools continue to be the main institutions to educate students not only for democratic society but also for their general education and preparation of them to live as decent citizens of the 21st century, the role of teachers on civic education continues to be essential.

\section{Teachers and democratic citizenship}

The schools, teachers and learning are factors that have special importance in preparing students for their roles and responsibilities as citizens of a democratic society.

According to Neubeck and Glasberg (2005) "schools reproduce the dominant culture of society by socializing students about what is valued and appropriate in the culture and what is not (p. 154)." In school, except the knowledge for democracy, students gain knowledge and democratic values as well. Therefore, teachers should create an environment where students exercise their rights and responsibilities, feel comfortable and safe, an environment where teachers create an opportunity to discuss some topics where students can express their opinions and their understanding for democracy and an environment where teachers are open to ideas and opinions of their students. According to Christenson et al.(2001) students must practice forms of civic discussion and participation consistent with the ideals of citizenship in a democratic republic (p. 32).

Also, teachers will create a classroom climate where such will promote tolerance, solidarity and readiness for cooperation. This will be achieved by:

encouraging students to analyze the basic concepts related to democracy.

encouraging students to express their feelings for democratic values.

encouraging discussion among students in their class for different views relating to democracy, ethnic tolerance, religious tolerance, respect for others, minority rights, civic rights and responsibilities, cooperation, etc.

encouraging students for participation in political and cultural life, etc.

To achieve these objectives, teachers must engage in equipping young people with different knowledge about the values, characteristics, and the role and importance of the development of democratic processes in a society. It is the obligation of teachers to prepare students to deal with various challenges that are the result of major changes that are occurring around the world today. Thus, teachers will help students to be prepared that they themselves are agents of change in the future. 
On the other hand, teachers need retraining, self-preparation and self-education in order to have the opportunity to be in step with the demands of time regarding the profession of teachers. They are asked to ensure that their education is conform the time demands on one hand, and on the other hand, teaching is different from the past.

According to Fehr and Fehr (2010), successful teachers want to be better or at least to teach differently tomorrow than today, and they are constantly looking for ways to make this happen. This perpetual search is not prompted by any desire to be deemed exceptional or bestowed with honorific accolades, but by recognition of the fact that every teaching act is unique, and modifications (and sometimes even abandonments) have to be made for subsequent engagements (p. 51-52). Also, we must not forget that "authentic teachers are always personally present in their teaching. They know that who they are has a tremendous influence on determining how they teach, and they are always alert to the implications of this reality for student engagement and learning. They readily admit that their personas may sometimes be problematic for some students and facilitative for others. They don't try to remove themselves from their teaching (this is impossible anyway) but try to broaden their repertoires of personal being to generate more instructional variety and diversity (Fehr and Fehr, 2010, p. 52)".

For preparation of a knowledge society, teachers must change themselves first and then the methods of teaching, because John Dewey was saying: " ... if we teach today as we taught yesterday, we rob our children of tomorrow ... " (Peake, 2010). Connecting to Dewey's saying we will say that all the reforms that are being made in our country, however, should be aimed at teaching different from that of the past, in order to not "steal" the future from our students. Teachers constantly have to think about the role and responsibilities that they have on students' achievements in all walks of life and not only for the success of their education for democratic citizenship.

According to Oakes and Lipton (2003) "teachers entering the profession in the 21st century are motivated by all the traditional reasons for teaching - a desire to help, a love of working with the young, pleasant memories of one's own schooling, fun, the intellectual challenge, a passion for the knowledge one gets to teach, an opportunity to "give back" what one has received, a paycheck for an honest day's work - the list goes on. But to these traditional reasons for teaching, many new teachers, will add another season - teaching for social justice - teaching to change the world" (p. 430). To change the world, teachers must achieve the objectives of the 21st century related to teaching and learning.

Who can help teachers in achieving their objectives?

Being in a transition phase, the entire society of Kosovo, its institutions and responsible individuals, especially those whose profession is connected directly to the education of young people must commit to completing the transition and prepare citizens for progress of a democratic society. In this context, various national and international documents support and obligate teachers to be successful in preparing their students for the advancement of democracy. Approval of the Council of Europe Charter on Education for Democratic Citizenship and Human Rights obliges teachers to engage seriously in preparing their students for the development of democracy in Kosovo. Charter is an important reference point and an important tool for teachers and all other individuals involved in education for democratic citizenship and human rights. Charter encourages and obliges teachers to work in this direction (Karta e Këshillit të Evropës për edukimin për qytetari demokratike dhe për të drejtat e njeriut, (2010).

In order to educate and create citizens of the 21st century, teachers are aided mainly by the social sciences in general and the subject of civic education in particular. A focus on civic literacy is a key part of 21st century skills. According to Taylor and Fratto (2012) core subjects and content are at the center of student learning (p.22). In this regard the subject of civic education, which in the Republic of Kosovo was formed as a separate subject, in this regard has a great role and importance. It represents one of the main sources of positive changes of civic awareness. The content of this course provides opportunities to our students, first and foremost will be educated to respect each other, to respect human rights, to express their opinion freely, to be participants in various social organizations, equality between people regardless of age, gender, political or religious affiliation, etc.

In these profound social changes and reform processes are found schools of all levels in Kosovo and University of Prishtina as well, where the Civics course has had and continues to have an important role. Its substantive content has a direct impact on the preparation of young people to overcome various difficulties and to understand the reasons and needs for deep social changes and to understand the reform process. This course helps the preparation of Kosovo citizens based on democratic principles.

Besides the subject of civic education, the Ministry of Education has prepared school curriculum and various materials to assist teachers in preparing and equipping students with knowledge dealing with democratic citizenship. Even a number of activities or training seminars organized in urban and rural areas of Kosovo have shown to be significant in this respect. 
Taylor and Fratto (2012) have concluded that our educational system must reflect our student's world or we will not only miss the opportunity to capture their attention, but also forgo their full potential to learn and grow (p.8). On the other side Brophy, J. (2010), talking about the role of teachers said that various studies have shown that the enthusiasm of teachers affects student outcomes. In this context, we should mention that teachers are very important to us because we are born small, defenseless, unthinking children. We must be taught to be thinking, competent, legal persons and citizens (Goodlad, 2001, p.12).

According to Fehr and Fehr (2010) "we must work together to achieve our common goal of raising for our nation a thoughtful, creative, well-educated, well-socialized citizenry (p. 23). In this regard, teachers have a key role.

In the end, we can say that all of these and other tools and materials help teachers to achieve goals for 21st century education issues.

\section{Research Methods}

For the realization of this research are used findings of a research project called "Concepts of citizenship among primary school students in Kosovo." The project is implemented by the Kosovo Education Center (KEC), Zurich University of Education and the University of Prishtina-Faculty of Education. The research used qualitative methods, quantitative methods, literature review, observation, and statistical methods.

Participants in the survey were the teachers and eighth grade pupils of Kosovo primary Schools. Teachers were of different ages, but most of the students involved in the survey were of age 15. They belonged to different ethnic and religious groups. The students were from urban and rural schools. The number of respondents is quite large. (See Tab. 1).

Table 1: Demographic statistics

\begin{tabular}{|c|c|c|c|c|c|c|c|c|c|c|c|c|}
\hline $\begin{array}{c}\text { No. of } \\
\text { municipaliti } \\
\text { es }\end{array}$ & $\begin{array}{l}\text { No. of } \\
\text { schoo } \\
\text { Is }\end{array}$ & $\begin{array}{l}\text { No. of } \\
\text { responde } \\
\text { nts }\end{array}$ & Area & $\%$ & $\begin{array}{l}\text { Year } \\
\text { of } \\
\text { birth }\end{array}$ & $\%$ & $\begin{array}{l}\text { Gend } \\
\text { er }\end{array}$ & $\%$ & $\begin{array}{l}\text { Ethnici } \\
\text { ty }\end{array}$ & $\%$ & $\begin{array}{l}\text { Religio } \\
n\end{array}$ & $\%$ \\
\hline \multirow[t]{10}{*}{36} & 142 & 1700 & $\begin{array}{l}\text { Urba } \\
n\end{array}$ & $\begin{array}{l}49, \\
4\end{array}$ & 1988 & 0,1 & $\mathrm{~m}$ & $\begin{array}{l}52, \\
6\end{array}$ & $\begin{array}{l}\text { Albani } \\
\text { an }\end{array}$ & $\begin{array}{l}87, \\
1\end{array}$ & Muslim & $\begin{array}{l}88, \\
6\end{array}$ \\
\hline & & & $\begin{array}{l}\text { Rura } \\
\text { I }\end{array}$ & $\begin{array}{l}50, \\
6\end{array}$ & 1989 & 0,1 & $f$ & $\begin{array}{l}47, \\
4\end{array}$ & $\begin{array}{l}\text { Serbia } \\
n\end{array}$ & 7,4 & $\begin{array}{l}\text { Catholi } \\
\text { C }\end{array}$ & 3,9 \\
\hline & & & & & 1993 & 0,1 & & & $\begin{array}{l}\text { Bosnia } \\
n\end{array}$ & 1,4 & $\begin{array}{l}\text { Orthod } \\
\text { OX }\end{array}$ & 6,9 \\
\hline & & & & & 1994 & 0,1 & & & $\begin{array}{l}\text { Turkis } \\
\mathrm{h}\end{array}$ & 2,0 & $\begin{array}{l}\text { Of no } \\
\text { religion }\end{array}$ & 0,4 \\
\hline & & & & & 1995 & 0,1 & & & Goran & 0,4 & Other & 0,2 \\
\hline & & & & & 1996 & 1,7 & & & Roma & 1,0 & & \\
\hline & & & & & 1997 & $\begin{array}{l}23, \\
0\end{array}$ & & & Ashkali & 0,4 & & \\
\hline & & & & & 1998 & $\begin{array}{l}63, \\
9\end{array}$ & & & $\begin{array}{l}\text { Egypti } \\
\text { an }\end{array}$ & 0,3 & & \\
\hline & & & & & 1999 & 9,5 & & & & & & \\
\hline & & & & & 2000 & 1,5 & & & & & & \\
\hline
\end{tabular}

In the first phase of research (2009-2010), the main instruments in the research were questionnaires for teachers and students (during the pilot phase) while in the second phase of the research (2011-2014) are compiled questionnaires for students only. The questionnaire includes several sections such as: section on schools, section on school curricula, section on the rights and responsibilities of citizens, the section for grades, etc. Each of these sections of the questionnaire can be functional even if analyzed and studied as part of the special research; hence, all sections of the questionnaire, analyzed separately from each other can freely appear as particular works. 
The first procedure of the research was the preparation of questionnaires for teachers and students. Then the pilot project was conducted in four schools of Prishtina. After completion of this phase of the research, data from questionnaires with SPSS program were analyzed, and some of the results of this pilot research are published in the form of a report. In the second phase of the research are also prepared questionnaires for research. Then it was developed a field research. After completion of field work, a database of 1700 questionnaires was created. The questionnaire which we have adapted to our needs has been standardized, and prepared by "International Civic and Citizenship Education Study".

It should be noted that students' questionnaire responses were confidential. The questionnaires were designed in such a way that anonymity of students is maintained. A similar policy was applied in preparation of questionnaires for teachers; however, the questions for teachers have been different.

These data are available to researchers who are engaged in research of citizenship education field. This paper is only a small part of our great research.

Results and discussions

Based on the results of field research in urban and rural schools in Kosovo, we can conclude that teachers are key factors in preparing students to contribute to the development of democracy in our country. Findings from the research represent the opinion of students on the role of the teacher in preparing students in the democratic spirit. Also, according to observation in the field of research it is obvious that teachers influence on students' personality creation continues to be great. Findings from the results of research analysis are answers to our research questions determined in this paper.

In the question: Teachers encourage students to decide in their view, we received these answers: 29,1 responded "often", 26.5\% "sometimes", 22.5\% "rarely" and 21, 8\% said "never."

In the other question: Teachers encourage students to express their opinions, we received the following results: $51.0 \%$ said "often", 21.2\% "sometimes", 14.3\% "rarely" and 13, 5\% of respondents said "never".

According Christenson, et al. (ed.) (2001) "teachers are often encouraged to examine persistent social issues and values dilemmas with students as a means of developing the knowledge, skills, and values important for citizenship in a democracy. Social studies provides an opportunity for students to wrestle with many of the issues and dilemmas they will face as citizens in a democratic society: individual liberty versus majority rule, cultural variety versus cultural assimilation, national security versus individual freedom, national versus state versus local community control, worker security versus employer rights, and global business competition versus the national interest" (p. 107). Studying such issues provides an opportunity for children to "work with others, learn how to handle conflict, solve problems, develop concern for others, and interact with the value issues that they encounter daily in their environment" (Evans \& Saxe, 1996, p. 231).

In this context, the question: teachers encourage students to discuss issues with people who have different opinions, shows us how teachers in Kosovo are interested to encourage their students to discuss different issues. In this question the students answered: $27.8 \%$ said "often", 35.5\% "sometimes", 21.2\% "rarely" while 15.4\% said" never ".

In the question: teachers present their points of view of various matters in different aspects when they explain them in class, the results are as follows: $28.6 \%$ answered "often", 37.6\% "sometimes", 22.3\% "rarely ", while 11.5\%" never ". (See fig. 1). 
Fig .1.

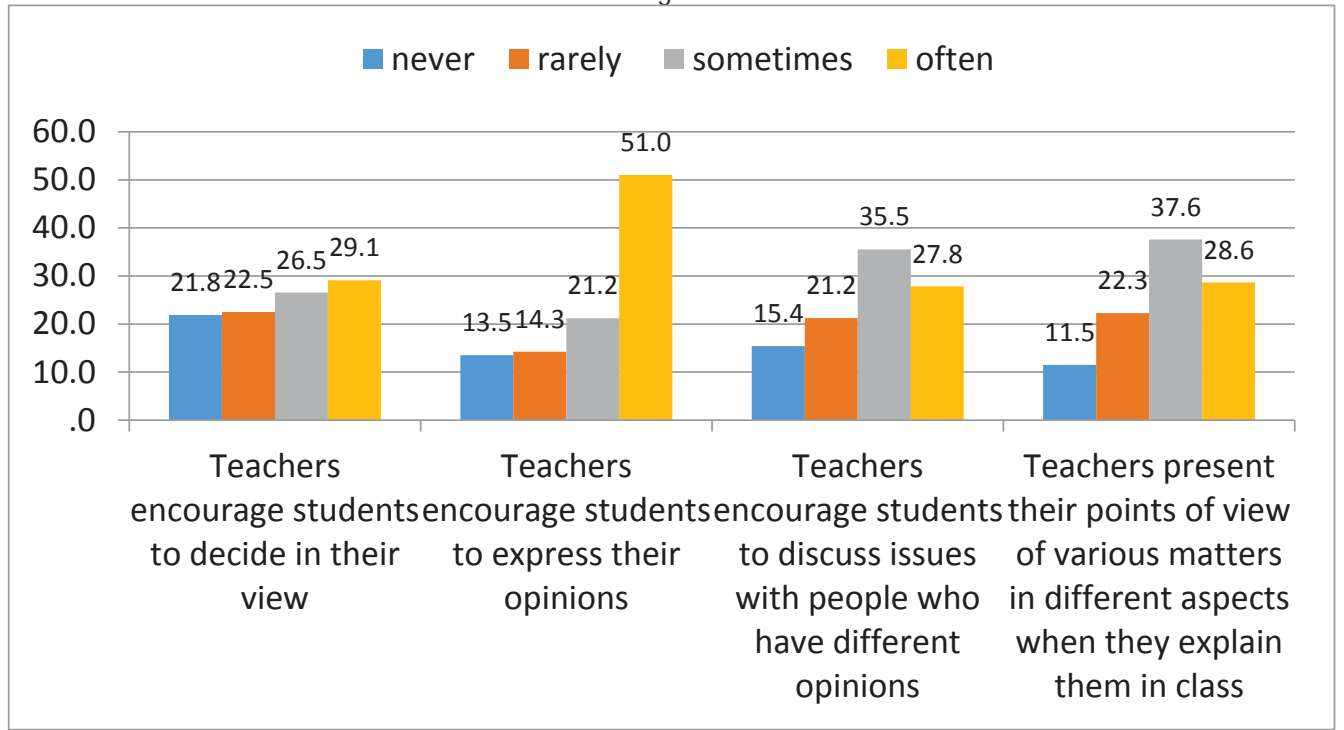

In the question: Students are able to openly express disagreement with their teachers: $12.4 \%$ said "never", $16.7 \%$ "rarely", 36.1\% sometimes, and 34.8\% "often".

In the question: Students express opinions in class even when they differ from the majority of other students, we have obtained the following results: 8.5\% "never", 13.6\% "rarely", 28.7\% "sometimes" and 49.2\% responded "often".

Nelson et. al. (2004) have concluded that "all important educational issues are also social issues, with interconnections to politics, economics, policy questions, ideology, and social practice - and certainly to our lives. These critical issues require critical thinking. Schooling issues arise in a context, not a vacuum, and the context includes historic and philosophic background as well as scholarly research that attempts to illuminate the issue (p.1.)". Having this in mind, in the questionnaire we have included several questions that have to do with political issue.

In the question that says: Students discuss current political issues in class, respondents answered: $41.6 \%$ "never", $32.2 \%$ "rarely", 17.0\% "sometimes", while 9.2\% said "often". (See.fig.2)

Fig.2.

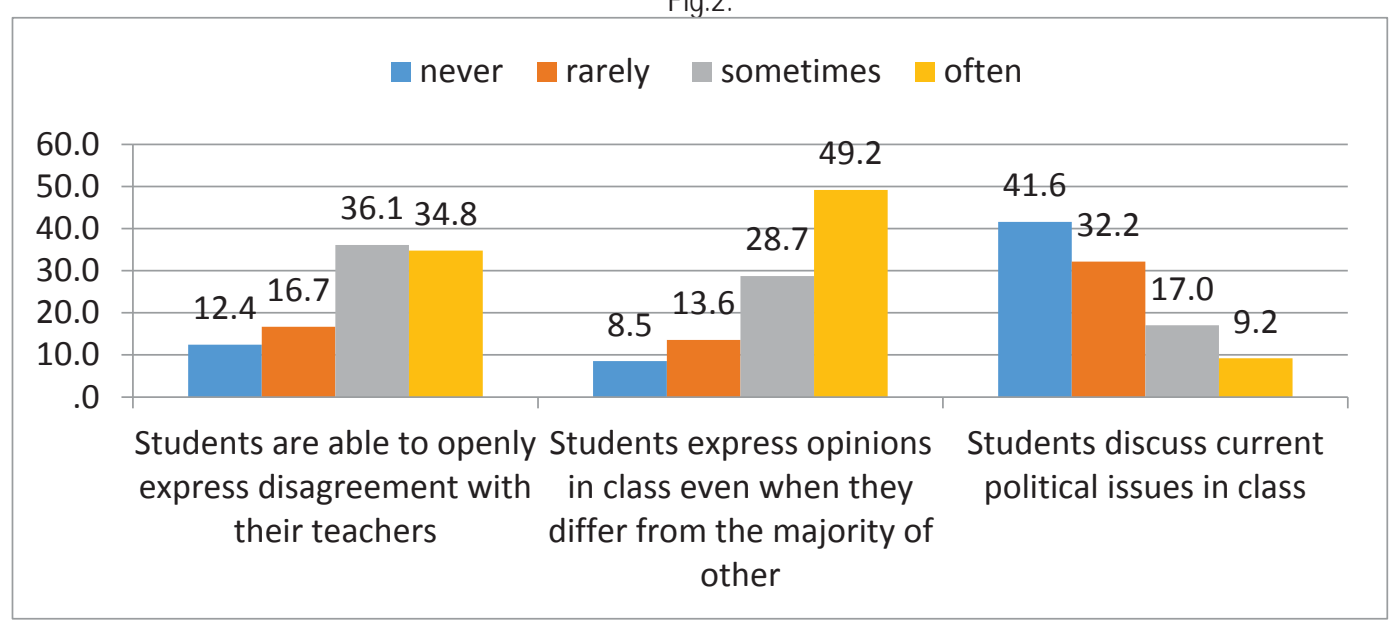


Another question that says: How often do you discuss about events in Kosovo politics with teachers? Students' answers to this question of the survey were: $29 \%$ said "never", 28\% "rarely", 26\% "sometimes", 12\%" often "and 5\%" always ". (See Fig. 3)

Fig .3.

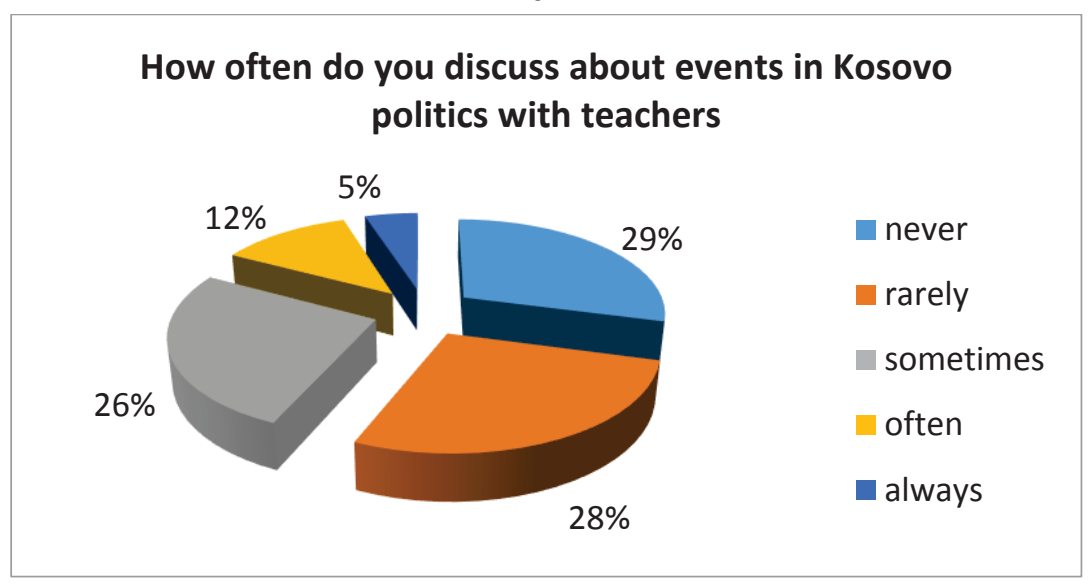

How often do you discuss current events in international politics with teachers? Respondents answered this way: $36.0 \%$ "never", 29.8\% said "rarely", 22.0\% answered "sometimes," and 8.9\% "often" , and 3.2\% have said "always". (see Fig. 4.)

Fig.4.

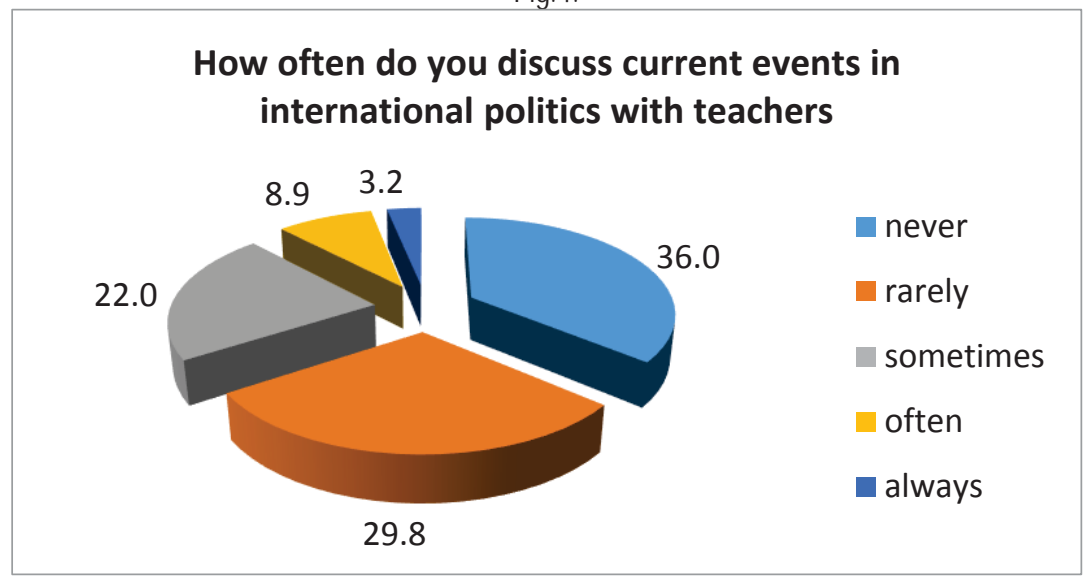

From the responses received from the survey questions, we need to think whether pupils are free to talk about various issues. According to Goodlad (2001) "Excellence is the product of teaching and is liberty's measure. There is no excellence without freedom. From Plato to Mill, philosophers have understood that only the free and self-sufficient can be virtuous. For them, so few were virtuous because so few were free. They understood virtues as the excellence of cognitive, affective, and associational practices: living well and living justly in the human world (p.12).

Fehr and Fehr (2010) have concludet that teachers have the ability to transform the learning environment through courageous acts of teaching. "We can transform the classroom into a place that challenges students to care about their educations and put forth their best efforts. We can transform schools to be a welcoming place that fosters life-long learning (p. 142)." In this context, besides this we can say that we are also focused to strengthen citizenship education. In this regard, schools are credible institutions.

In the question: How much do you trust these social groups or institutions, among which were also the school institutions, students have expressed their opinion that they strongly believe in their schools. $79 \%$ of the total number of respondents responded positively and said they fully trust schools. 15.7\% partially believe in schools, $4.2 \%$, little, while only $1.2 \%$ of students have lost confidence in the school. Trust in schools continues to be very high. 
The research results dealing with this issue have given these figures-answers presented in Fig, 5.

fig. 5 .

\section{How much do you trust these groups or institutions? (Schools)}

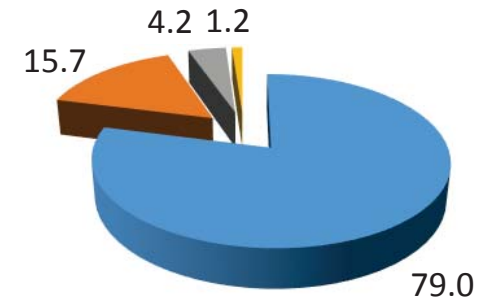

- fully

partially

little

not at all

According to White and Walker (2008) "The overt goal of our schools is to enhance knowledge, skills, and values development for our children. Unfortunately these goals are too often top-down and authoritarian and promote passivity. These goals therefore seem to be driven by the purpose of preparing our youth for the world of work. This is realistic goal for schools but should not be the driving force. Ultimately, we must prepare children for active participation as global citizens, which means that we have a responsibility to teach for social efficacy (p. 1-2)". Social efficacy depends on the school, by teachers as well as other relevant factors.

Processing, analysis and publication of results from this research is being done with the aim of sensitizing professionals and the general public regarding various issues related to civic education in Kosovo.

\section{Conclusion}

Teachers always were considered the main agents of educational policy implementation. They should be aware of their responsibilities as agents of social change. In fact, the role of teachers as agents of change in the wider society is absolutely essential and an acceptance of this role requires courage to resist and problems to deal with possible challenges of different nature. To overcome these challenges, they themselves must have adequate professional preparation.

In this context a new challenge in Kosovo is preparing students to contribute to a democratic society. Their own profession obliges teachers to be key factors that help students to influence the development of democratic processes in the country. Thus, helping in this aspect, teachers are required for readiness, willingness and adequate preparation. In this regard teachers can help us more. They should be able to prepare and guide new generations because teachers are considered "helmsman of the future". However, it is not enough that they are only good navigators. They should know what the goal they are seeking to achieve is. Also, they should be aware that their way is not easy. During their journey they will encounter various problems and these people need to know how to overcome the problems they will encounter on their way to the intended target.

In order for Kosovo teachers to be professionally prepared and to overcome the challenges that Kosovo society is facing today, as well as to lead their students towards a democratic society, training programs and numerous activities in this direction are being developed for them. Such arrangements are made by various national and international organizations and educational institutions.

Finally, we can conclude that we need qualified teachers. As changes continue to take place in our world, competition for qualified educators will increase dramatically.

\section{References}

Brophy, J. (2010). Motivating students to learn. 3rd ed. Taylor \& Fracis. 
Christenson, M., Johnston, M., \& Norris, J. (Eds). (2001). Teaching Together: School/University Collaboration to Improve Social Studies Education. Maryland.

Evans, R. W. \& Saxe D. W. (Eds.) (1996). Handbook on Teaching Social Issues, Washington D.C.

Fehr, M. C. \& Fehr, D. E. (Ed.) (2010). Teach Boldly!: letters to teachers about contemporary issues in education. New York.

Goodlad, S. J. (ed.) (2001). The last best hope: a democracy reader. 1sted. San Francisko.

Neubeck, K. J., \& Glasberg, D. S. (2005). Sociology: Diversity, Conflict, and Change. McGraw-Hill.

Nelson, J. L., Palonsky, S. B., \& McCarthy, M. R. (2004). Critical issues in education: dialogs and dialectics. 5th ed. The McGraw-Hill.

Oakes, J. \& Lipton, M. (2003). Teaching to change the world. 2nd ed. New York. The McGraw-Hill.

Peake, J. (2010, November). "If we teach today as we taught yesterday, we rob our children of tomorrow". Retrieved from http://connection.ebscohost.com/c/opinions/56670557/if-we-teach-today-as-we-taught-yesterday-we-rob-our-childrentomorrow

Taylor, L. M. \& Fratto, J. M. (2012). Transforming learning through 21st century skills: the who took my chalk? TM model for engaging you abd your students. Pearsons Education, Inc.

White, C. \& Walker, T. (2008). Tooning in : essays on popular culture and education. Rowman \& Littlefield Publishing Group, Inc. Lanham, Maryland.

Karta e Këshillit të Evropës për edukimin për qytetari demokratike dhe për të drejtat e njeriut. (2010).Retrieved from http://www.coe.int/t/dg4/education/edc/Source/Charter/Charterpocket ALB.pdf

Zmuda, A., Kuklis, R., \& Kline, E. (2004). Transforming schools: creating a culture of continuous improvement. USA, ASCD. 